\title{
DYNAMICS OF THE MERCHANT ELITE IN EARLY OTTOMAN MODERNITY OF THE SOUTHERN FRONTIER: THE CASE OF SALT IN TRANSJORDAN AND NABLUS IN PALESTINE
}

\author{
EMAN ASSI \\ American University of Ras Al Khaimah, United Arab Emirates
}

\begin{abstract}
This paper provides a comparative analysis of the evolution of the central hall plan in the city of Nablus, Palestine, and the city of Salt in Jordan. Both cities were southern Ottoman frontiers in the late nineteenth century. They both became the capital of Liwa Al Balqa, a regional administration center connected to Al Bab Al Ali in Istanbul. This situation allowed Salt City to transform from rural to urban settlement and allowed the city of Nablus to increase its trade network with the surrounding villages to become one of the most important regional centers in Palestine. This paper argues that the emergence of a central hall plan in the southern Ottoman frontiers was influenced by merchants who redefined the urban economy and landscape in the region. One key aspect is to search for the dynamic relationship between rural-urban and merchant-peasant dimensions during that time. The paper will focus on typological and morphological analysis of both cities during the twentieth century. It will discuss similarities and differences between the two cities and how their social urban morphologies have developed as a response to the dynamic relationship between the merchants and rural context.

Keywords: urban economy, modern heritage, cultural exchange, Ottoman history, central hall house.
\end{abstract}

\section{INTRODUCTION}

Many scholars have discussed the modernization of the Late Ottoman period recently [1]. Most of them have looked at the influence of Tanzimat in certain areas [2]. Doumani unpacked the social history of Nabulsi merchants and peasants by exploring the relationship among culture, politics, and trade in Nablus. Al Salem investigated the complex of administrative reforms and their impact on larger coastal sites of the region, taking the city of Tulkarm as a case study [3]. Abu-Hilal studied the central hall houses in Hebron through placing these houses in their architectural [4], social context. Rogan documented the case of Transjordan to see how the Ottoman State restructured and redefined itself and its frontier that led to the creation of the new Middle East [5]. Saliba investigated the genesis of modern architecture in Beirut during the early phase of Ottoman modernization [6]. He focused on how modernization influenced the evolution of the central hall in Beirut during 1840-1940. This paper will build on previous findings in this domain by conducting a comparative analysis of two southern Ottoman Frontiers. The city of Nablus and the city of Salt were selected as a case study. This paper will investigate the different evolutions of architectural and urban landscapes of the city of Salt and the city of Nablus.

Ottoman modernization starts in the nineteenth century through sets of regulations called Tanzimat. The main aim of Tanzimat was to consolidate the military and regulate the ottoman administration system [7]. A new land code replaced the outdated system of taxation. Each land title was then related directly to the fiscal system. More clear hierarchy of authority was established through the new up to date juridical infrastructure in 1864.

According to Arnuld, Ottoman modernization as a movement was not synchronous one, some cities took off before others. It was not a matter of re-composition but represented a break with regards to modes of administration, to the division of social group and activities 
within space and architectural and urban form. Despite the application of the same legislation and means of exercising power, modernization as a process of transformation in Bilad Asham was different to the one in Anatolia. Those cities that played the role of entrance point for merchandise, and for western influence, started before others. Nevertheless, other cities swiftly caught up with them and even passed them [8].

In 1836, Mustafa Reshid Pasha, known as the father of the Tanzimat, proposed to the Sultan a series of measures aimed at improving the layout of the city and avoiding the spread of fires. His suggestions were substantially taken into account. These measures as a form legislation was subsequently the subject of further specific rulings (1848). In 1863, it was extended to all the cities of the Empire. This legislation was partially applied for many reasons; first, the legislation was prepared in Istanbul, though designed for all the cities of the Empire. It was produced by writers who resided in the capital and whose main objective was to control construction there, and especially to reduce the risks of fires. However, these wooden constructions, largely open to the exterior by means of paneling, were quite different from most of those erected in the Arab provinces, which were rather made out of stone, brick or cob. Hence, the imperial regulation was applied in variable manner, according to local particularities. This was the case in Damascus, where the legislation corresponded poorly with the practical knowledge of construction professionals [9].

The Ottoman strategy in constructing the new district shifted authority away from established local and regional leaders toward new towns, which previously had not held political or economic power such as Salt in Jordan and Tulkarm in Palestine. The Ottoman combined centralized administrative practice with decentralized practices by the incorporation of intermediate groups like grant landholders and tax farmers into the central administration [10]. This new policy started in 1839 and reached a new stage by 1858 with the Ottoman Land Code. The shift of authority from already established urban centers to new rural areas, which were then treated as a new frontier, had helped to create new socio political orders separated from the large empire institution.

Starting in 1867, the Ottoman government undertook a new round of initiatives in its frontier zones, drawing on new Tanzimat legislation, which developed the state's infrastructural power to create an enduring administrative apparatus at the periphery [11]. The elements of the modern Ottoman state that the Tanzimat created were applied to the frontier zones in stages as local acceptance of the Ottoman rule became generalized, and the state developed the means to intensify its presence. The fundamental unit of provincial administration within Tanzimat state was the juridical district, or the kaza, which brought together a district governor, a treasurer, and a judge, as well as the clerks needed to keep the books and armed forces to keep the peace. Thus, the creation of kaza introduced the institutions of a state bureaucracy and judiciary manned by civil servants who were moved among similar posts in different provinces of the Empire.

The provincial reform law also called for the election of local representatives to administrative councils, municipal council, and court systems to enable members of the local community to consult with the district governor and represent communal interest. In this way, the state introduced new notions of political participation through elections and public office that gave local communities interest in the new forms of the state rule. As these instruments of state took root and provincial authorities succeeded in raising taxes from the frontier districts, the state began to extend its infrastructural power through communications networks, which included ports, shipping, roads, post and telegraph connections, and railway lines. The state also began to provide essential social services by opening schools and hospitals [12]. 
The extension of direct Ottoman rule also led to a series of transformations in the economic life of frontier districts. Enhanced security, regulations of weights and measures, and growing monetarization encouraged the development of markets, which, in turn, attracted merchant's participation in the state's project of direct rule in economic terms [13].

\section{MERCHANTS}

The city of Nablus was the most important urban center if you consider the rural surroundings in north Palestine. Its power gained of being the connection of rural centers to the central Ottoman administration. In order to maintain relative autonomy, the city of Nablus has to provide the peasants with commodities and to offer them the service they need and certain political and cultural channels to the ottoman administration. The implementation of Tanzimat led to a transformation of the old social system to one characterized by centralized bureaucratic government. This transformation was a turning point in which power shifted from the old upper class to landowners, office-holding aristocrats, merchants, and businessmen.

Ottoman centralization influenced the direction of commercial flow during the Tanzimat period. As a result, Nablus become closer to the Great Syria politically and economically. Serval infrastructure projects was implemented during the second half of the nineteenth century which strengthen the connection among cities, such as Cairo, Damascus, Beirut and other cities. Many services were also initiated in this period. It was a period where new roads networks, port expansion, railroads and telegraph line was constructed. Certain manufactures expanded their business to the other areas such as rational textile manufacture. Textile merchants of the city of Nablus were tied to Cairo in the first half of the nineteenth century but later and because of the changing of regional trade network, textile trade shifted from Cairo to Damascus and Beirut [14].

The Ottoman relied on the notables as intermediaries between the state and society. This merchant notability emerged as new elite in Trans Jordanian society following the introduction of direct Ottoman rule in 1867. Merchants from neighboring Syrian and Palestinian cities, who were attracted to Transjordan by the security of direct rule and the economic potential of the region, advanced the government's interest in several ways: by accelerating the monetarization of the economy; by finding outside markets for the regional products, by investing in the local economy and enhancing its productivity. In effect, the merchant elite linked Transjordan to the regional economy as the government-linked the region to the provincial administration. In this process, the merchant's notability displaced the indigenous elites, providing the Ottoman with intermediaries between state and society who had a vested interest in the Ottoman order.

In Nablus and during the end of the eighteenth century and beginning of the nineteenth century, a new type of elite has emerged, who had relative political to rule the economic discourse. The changing political situation because of the new legislation of Tanzimat gave the merchant elite the opportunity to benefit from their connection with Ottoman central administration to expand their business and trade through lending money to the peasants who need it for their agricultural production. The Nablus advisory Council became the main body for the new emerging type urban elite who also negotiate with the ottoman government over their boundaries of their political authorities.

\section{OTTOMAN TRANSJORDAN}

The Ottoman attention to Transjordan has started after the Tanzimat. The changing political situation allow developing new situation of emerging flux that settled in Transjordan. Several Communities emigrated from different parts of the world and settled in Jordan, among them 
Criscassians and Chechen from Russia [15]. Urban merchant from Nablus settled in Slat and later involved in the agricultural activities. They stayed there until the mandate was established. These immigrants played a big role in foundation of the national economy.

During this time also, new Christian missionaries from Europe settled in the Jordan and in Salt in particular. The main aim of these missionaries is to escape from the orthodox and ottoman influence, which is relatively weak in this area of Transjordan. The Christians were able to create physical changes in salt environment. it had transfer gradually from rural to a more urban. New churches, and new educational and medical system was introduced

Christian missionaries were another major catalyst for change. Missionaries were the only European residents in Transjordan. Western missionaries were attracted to Transjordan because of its frontier isolation, which meant that Ottoman and Orthodox influence were at a minimum. In addition to building churches, missionaries introduced modern education and medicine through the opening of schools and clinics. Both had radical, often destabilizing consequences on the population. These three agents of change - the Ottoman state, Syrian merchants, and European missionaries - did not work in isolation from one another. The Ottoman sought to encourage the merchant presence, and merchants sought positions in local government.

The application of the 1858 Land Law in Transjordan set in motion the process of the registration of land and encouraged a market in landed property. Merchants from the surrounding cities expanded their operations in what they took to be an economic frontier. The primary attraction was agriculture production in the region at the time, but merchants diversified their economic activities to include money lending and the accumulation of agriculture property. The activities of merchants drew Transjordan into a regional economy of Ottoman Syria and the Mediterranean world beyond. The law also called for the creation of administration councils composed locally elected representatives for the governor to consult and be involved in administrative decisions affecting the district.

Dawod Afendi came from Nablus as a merchant, one of many traders who took advantage of the newly established Ottoman presence to enter the Transjordan market. He bought, and he built shops and warehouses for the storage and sale of commercial goods: manufactured products from Palestine for the local market, pastoral and agriculture products from Transjordan for resale in Palestine towns.

Building on the commercial advantages of the Tuqan family trade network, Dawud Efendi diversified his activities in Salt from trade to money lending. Products in Transjordan faced a new need for cash in the changed circumstances of direct Ottoman rule. Taxes had to be paid on land and harvest, and many of the transactions in the market were now conducted in cash rather than in kind as before. In the transition from a barter to a cash economy, a real need existed for coinage in which urban merchants like Dawud Tuqan were well placed to satisfy. Between trade and moneylending, Dawud Efendi has established a network of contacts with hundreds of cultivators and pastoralists across Balqa districts. At the time of his death, tens of thousands of piasters in loan outstanding were left, and tons of grains purchased ahead of the harvest due to his estate, which his survivors had to recover through the Islamic court of Salt.

Through these contracts, Dawud Afandi Tuqan came to acquire landholding and livestock, numerous, vineyard and plots of farms, as many as 61 goats, 211 cows, according to the inventory of his possessions. Dawud Efendi Tuqan commissioned an architect from Nablus, Abdel Rahim al Aqruq, to design a suitable home in the heart of the newly commercial district of Salt, known as Nabulsi Quarter. The Tuqan building combined residential and commercial functions, with spacious shops and secure storerooms built into the hillside on the ground floor and elegant apartments with an internal courtyard open to the sky on the upper floor. 
The Tuqan building imparted a new level of architectural sophistication to the town of Salt. Where most of the traditional houses in Salt have a basic structure built from rough stone, skilled masons and artisans built the Tuqan Building using fine stonework, wrought iron decoration, and elaborate windows. One of the living rooms even had a balcony, facing the busy commerce of Sharia al hammam (Bath Street).

\section{COMPARATIVE ANALYSIS}

Although the central hall house was originated about 3,000 years ago, the style became well established in the 19th century and is now the most identifiable and preferred house type in Lebanon and was popular in Syria, Palestine, and Jordan. The origin of the central hall plan may be the Roman atrium.

The Roman atrium house in Lebanon as described by many scholars has centralized plan where rooms are organized around three sides of the open court. It is a two or three stories high. Most of the Roman atrium house is symmetrical. The entrance is indirectly related to the main court to provide more privacy to the residence and it is never located from the threearcaded side.

The central hall plan, which is considered an evolution of the open courthouse, emerged first in Beirut. It was then transferred to other cities of Bilad Al Asham [6]. After the establishment of Beirut as a capital of Villayet Sidon in 1832, under the Egyptian Occupation, Beirut became the most important city in Great Syria. It attracted many foreigners to settle. Its port developed and became the main coastal port in Great Syria. Most foreign trade from other inland cities such as Damascus had to go through its port. During the period of 18401864, Beirut underwent massive transformation. Many public building and major infrastructure projects were constructed. The establishment of the French ottoman bank in 1850 , the building of wharf and the construction of Beirut Damascus cross-mountain road was open are all made Beirut the main port of the region.

The social role of merchants was influential, as were their economic activities. Merchants emerged as distinct social elite. This was reflected in their relations to the Ottoman and their displays of wealth and hospitality. The homes that leading merchants built in the last decades of Ottoman rule still stand as a testimony to their social position, imparting an urban sophistication, which sets them apart from other residents of Transjordan. This section contains a comparative analysis between the central hall plan in the city of Nablus and the city of Salt. The comparative analysis is structured according to the following:

1. The dynamics of the urban economy in the region;

2. The urban morphological analysis of the city of Nablus and how it differs from Salt; and

3. The evolution of architectural typology in both the city of Nablus and the city of Salt.

\section{THE DYNAMICS OF THE URBAN ECONOMY IN THE REGION}

The city of Nablus was the most important city of Ottoman Palestine in the eighteenth and the nineteenth centuries. Historically, Nablus was a place where many important civilizations have developed. All the time, the city maintained economic activities, density of population and political power. It gained certain degree of autonomy and was the main regional trade center of the region. It has a good local deeply rooted network with hinterland.

The urban-rural relationship or merchants-peasants relation was essential to the political economy and cultural life of Palestine. Its location close to many villages, surrounded by rich agricultural land, contained a good density of people and villages and it has a manufacture base. All this allow the city of Nablus to become the economic Centre of Palestine. Although Nablus is important but it is different from Damascus. Damascus was the administrative capital and a large metropolis, where Nablus was not. What make Nablus unique was its 
strategic natural location in the heart of the fertile agricultural hinterland. It location at the main natural corridor for good moving in different directions allowed the Nabulsi to travel to many cities and in different direction; Safad, Nazareth, Jerusalem, in the hill areas, Jafa, Haifa and Gaza along the coast, salt, Huran to the north and east (Fig. 1).
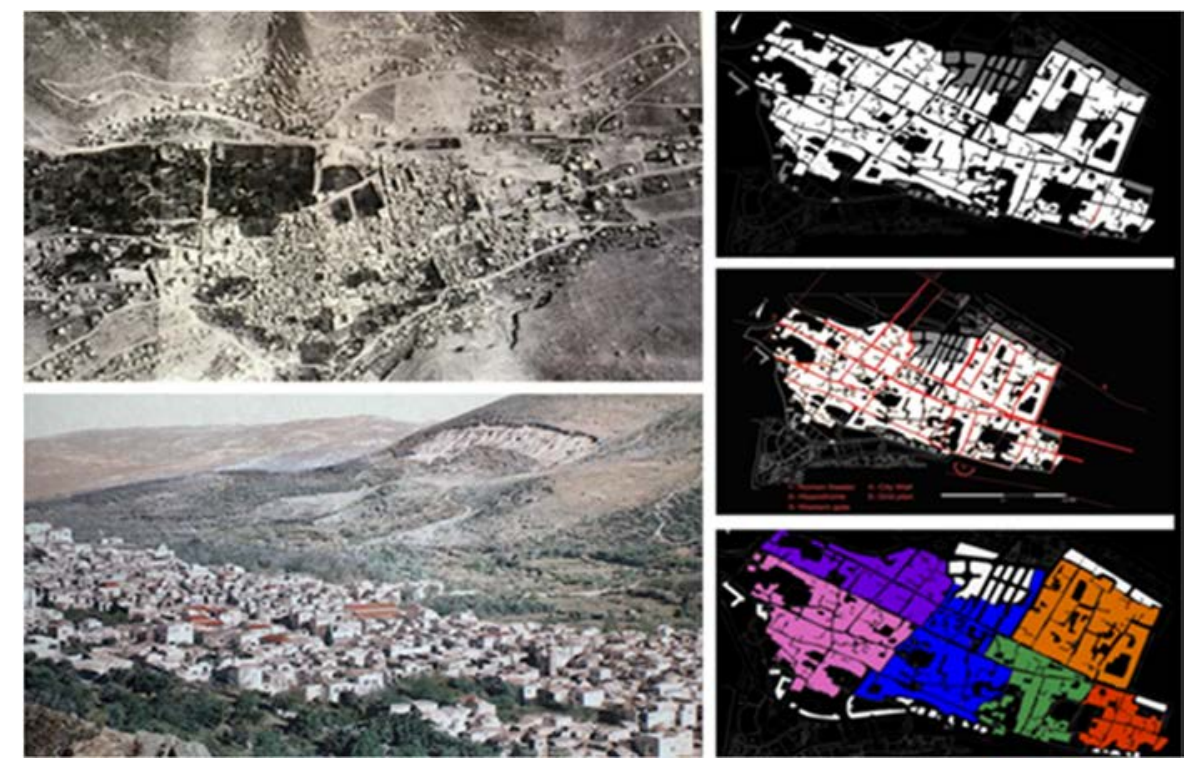

Figure 1: History of the development of urban morphology in the old city of Nablus. (Source: Research by Dr. Maath Taher.)

\section{THE URBAN MORPHOLOGY}

Urban morphology of the city of Nablus is strongly affected by its essential economic role during the Ottoman rule. This role has strongly influenced the shaping of the historic urban fabric. More than 30 soap factories, eight Turkish baths, and several sophisticated houses and palaces of wealthy merchants have contributed to the unique architecture traditional style and rich urban fabric of the city. Hundreds of shops line the two main axes that run from east to west, reaching both ends of the city and intersecting at one point, forming a public plaza in front of the main mosque. From this commercial strip, you can reach through narrow dark alleys to the different neighborhoods.

The city of Nablus, like any other Arab Islamic city, is divided into different neighborhoods; each represents a self-sustained unit that has its territorial boundaries. The main driving concept for the organic arrangement of the neighborhood is privacy. It happens through gradual transition for the main public road to the semi-public smaller close-end road that leads to the neighborhood. There are six major neighborhood in the city. Each neighborhood is related to the main suq. All the houses are organized around different level of open courts. Most of the roads that lead to the neighborhood is dark and narrow for more privacy. In some places the masses of the elevation meets covering the road beneath creating a very vivid experience of light and interesting visual experience. Major parts of the old city is located in the valley between the two mountains, while the rest is climbing gradually the southern mountain, which called Mountain Gerzim. 
The urban morphology of the city of Nablus is different from the one in Salt city. While Salt has expanded on the hills of the surrounded mountains, most of the urban fabric of Nablus lies in the valley where the two mountains meet. Building outside the wall of the Old city developed at the end of the nineteenth century. According to Ihsan [16], the first house that was built outside the wall was in 1889 was that of Abdallah Ataher on Mount Ebal, shortly after, a missionary initiative built Mar Yousef Monastery originally as a health clinic in 1888. Many buildings were built in the same period, including the Alfatimeya School, Algazaliyeh School, and the Public Library. The city was very prosperous in the late nineteenth and early twentieth centuries until the British mandate, which was followed by the earthquakes. This allowed for a central hall house as a new type of house began to emerge.

\section{TYPOLOGICAL ANALYSIS}

The key issue for this text is the rise of notable families during the late Ottoman period. Those notable families were merchants of regional political and economic power, benefiting either from the surplus of the villages in the case of Nablus or from the new Ottoman Tanzimat, as in the case of Salt, allowing for a unique urban social structure to develop but with different patterns in both locations. In the city of Nablus, the typology of the merchants' houses was transferred to other surrounding trade networks like throne villages and Slat in Jordan. When, for example, the Abdul Hadi Palace in the Old City of Nablus is compared to Abdel Hadi Palace in Arrabeh, one of the throne villages [17], many similarities become evident. The difference is that Abdel Hadi Palace in the old city of Nablus was not an isolated building, as in the case of Arrabeh (Fig. 2).

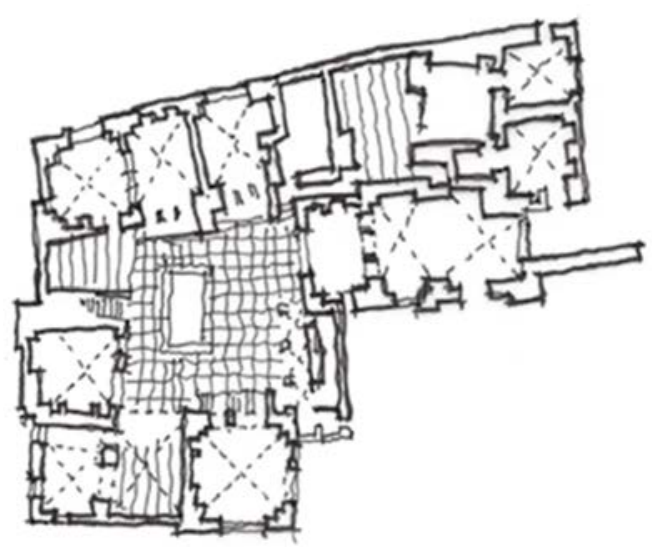

(a)

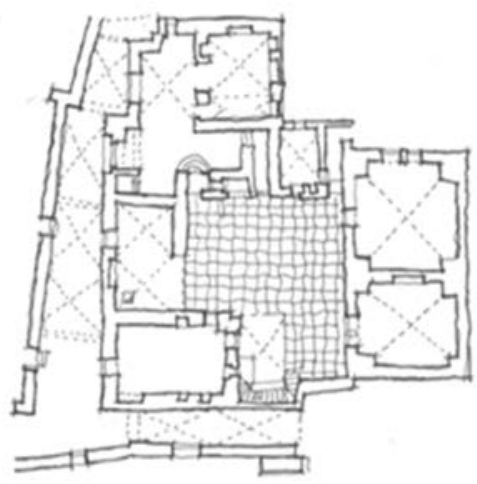

(b)

Figure 2: (a) Plans of courtyard house of Abdel Hadi family in the Old City of Nablus. Source: Booklet on Nablouse L, architecture d'une Ville, 2002, supervised by Philippe Revault, Serge Santelli, and Cathreine Rochant; and (b) The plan of the courtyard house of Abdel Hadi family in Arrabeh. Source: Habash Consulting Engineering.

Many Nablusi merchants moved to Salt after the new Ottoman Tanzimat seeking more trade opportunities. They were mainly well-established Nabulsi merchants. The Touqan, Nabulsi, Masri, Mihyar, and Belbeisi families were Nabulsi elite families who moved from Nablus and settled in Salt in the early twentieth century. When they moved, they carried their 
already existing urban traditional knowledge with them and tried to adapt that knowledge to the new rural context and topography of Salt City. Gradually Salt was able to develop its unique architecture. The process of adaptation of central hall type has to follow the slope of the mountains of Salt.

A new type of central hall was emerging that had new characteristics but, at the same time, shared some similarities and differences from the ones in Nablus. The central hall plan house or as sometimes called the three bays house, in Nablus was located outside the borders of the Old City. It is an isolated structure; following the new building law of applying a set back from four sides of the building. This was not the case in Salt. Most central hall plan houses or the other mentioned types were attached on more than one side. In many cases, these houses were part of a linear continuous commercial strip attached from both sides, leaving the ground floor for shops and the main house on the upper floors. This following text will focus on the traditional house typology and will be divided into two parts, the courtyard house found inside the Old City and the central hall type outside the walls of the Old City.

1. The courtyard house type: Is an indigenous type that was applied and developed until the early twentieth. Its design is similar to any Arabic or Islamic house. It is an inwardlooking design scheme with a central area open to sky courtyard. Around this courtyard, several rooms and spaces are grouped, and all are linked directly to it. These courtyard houses were built attached and comprised one mass. Most of the houses have only one elevation that faces the street, while a few larger houses may have two elevations minimum windows in the front elevation. Most of the windows were looking into the courtyard to achieve more privacy for women inside. The scale and proximity of the house were determined according to the economic and social status of the owner of the house. This scale ranges from two to three rooms to a large house that has different wings and several courtyards at a different level.

2. The three-bay house: This type is called a central hall. They are found outside the old city of Nablus, and most of them date back to the early twentieth century. The central hall type is an extroverted layout scheme with many openings to the outside. All the rooms are directly linked to the main hall in the middle. The decoration of the façades has a Western influence, especially the entrance where Corinthian columns can be found. Steel I-beams were introduced instead of a vaulting system. This style evolved in Palestine during the period of the British Mandate (1918-1948). According to Fathi and Refai, this type of house was developed first in Lebanon and then found its way into Syria, Jordan, and Palestine during the 1920s [18]. New planning regulations were introduced during that time, which allowed the city of Nablus to expand outside the old city borders. New roads were constructed, new residential quarters were established, and a new building law was enforced. One hypothesis for this development was that the main concept of building law is based on having a setback that encouraged the emergence of a new building typology. The other hypothesis is that the three-bay house or central hall type is the development of a courtyard type. The open courtyard was covered and transferred to a central hall, which proved to be climatically more convenient (Fig. 3).

The three-lane type can be found in two versions, the simple lane type and the extended lane type. The simple lane type can be found in these cases:

- Case one: The house is composed of 3 lanes by 2 lanes. This is the simplest configuration. The central hall is surrounded on both sides; on one side is the entrance, and the other side has three-bay openings (Fig. 4(a)). 

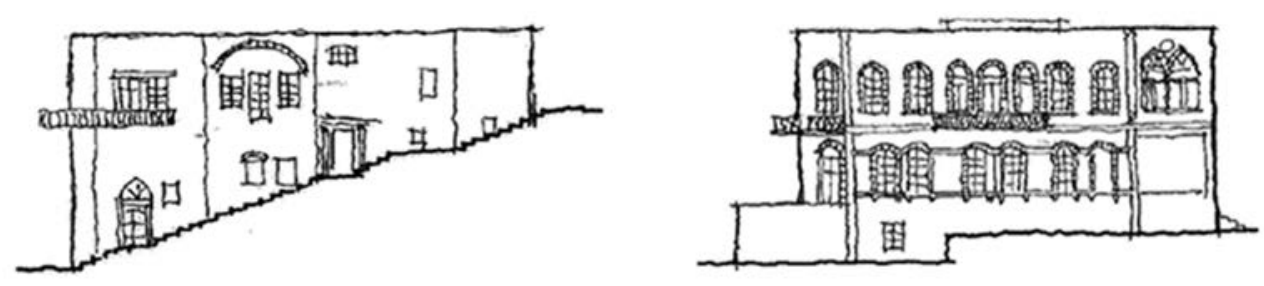

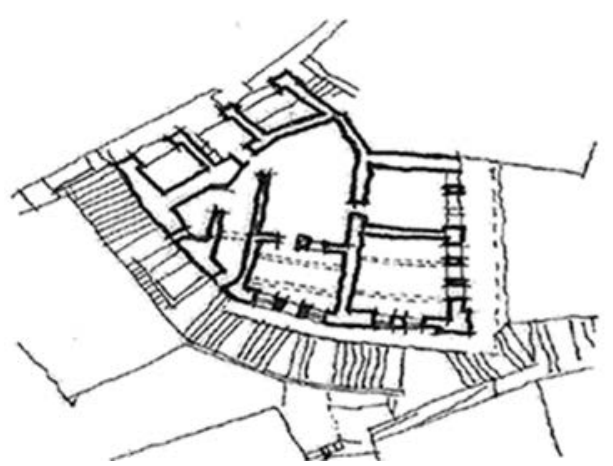

(a)

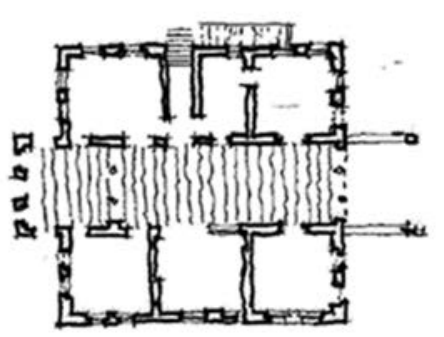

(b)

Figure 3: (a) Plan and elevation of an An-nbulsi house, Salt. (Source: As-Salt Greater Municipality, Unit of Development Projects Management); and (b) Plan and elevation of a central hall plan in Nablus. (Source: Students of An-najah National University.)

- Cases two: The house is composed of 3 lanes by 3 lanes. The central hall might be extended till the end of the house, where one side is the entrance, or the central hall is surrounded by rooms from one side, leaving the other side for the window. The room arrangement is symmetrical (Fig. 4(b)).

- Case three: The house is composed of 3 lanes by 4 lanes. The central hall might be extended until the end of the house, where one side is the entrance. Alternatively, the central hall is surrounded by rooms from one side, leaving the other side for the window. The room arrangement is symmetrical (Fig. 4(c)).

The extended lane type can be found in these cases:

- Case one: The central hall extends outside the main façades of the building. This could be a covered entry with decorated columns or Bau house style verandah (Fig. 5(a)).

- Case two: One of the lanes is extended, breaking the symmetry of the composition slightly. The main purpose of the addition is to get more additional space (Fig. 5(b)).

- Case three: The central hall might extend, and one side of the two lanes extends to gain more space. The added unit could be a service (Fig. 5(c)).

- Case four: A whole mass is added to the central hall lanes that are composed of three lanes. The entrance is still through the main hall. This type is found in big houses that reflect the social and economic status of the owned and could also be on two floors (Fig. $5(d))$. 

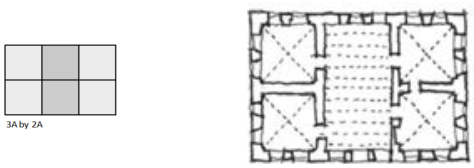

(a)
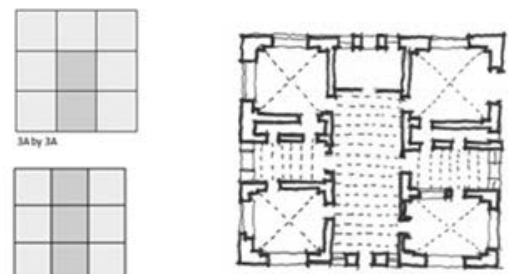

(b)
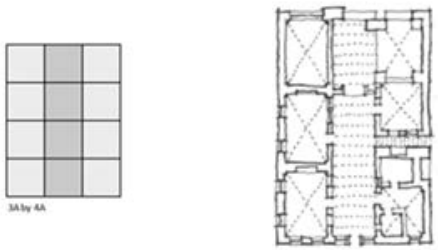

(c)

Figure 4: Simple three lane type.

\section{CONCLUSIONS}

The early phase of Ottoman modernity was influenced to a great extent by the Tanzimat or Ottoman reform in the late nineteenth century. Salt was the most important center of commerce in the Transjordan and Nablus was its primary trade partner. There was a monthly caravan from Nablus. Tanzimat drove the urban economy and was facilitated by new modes of networks and production, which influenced the urban and architectural urban and rural landscape. As a result, of this modernization, a central hall type was a new house type emerged in this period. This new type was flexible and at the same time able to maintain the innate qualities of the already exiting traditional courthouse type. The central hall house had also the ability to respond to the new social and economic change and reshaped itself according to diffident topographic locations. This situation was applied in the city of Nablus and salt. In Salt the central hall house shaped itself to the constrains of urbanization without losing its intrinsic consistency and its architectural character. In Nablus, although the new central hall house had spread in new area outside the old city, it had integrated to the architectural character and physical fabric through certain design qualities, such as the height of the buildings, the size of the block and the setback requirements.

The central hall house, with its triple arch, is considered the most distinguishing architecture feature outside the city wall of Nablus. The type of house is regarded as an important icon and a source of architectural identity. In the city of Salt, the central hall house was not only a significant architectural structure, but it had also transformed and redefined the rural landscape to become an urban center and the most important city in Transjordan. In both cases, the central hall house with its triple arch was a hybrid suburban structure resulting 

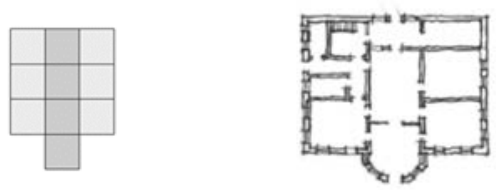

(a)
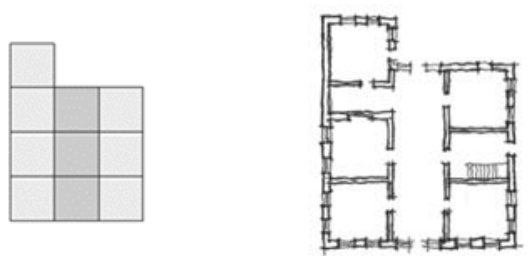

(b)
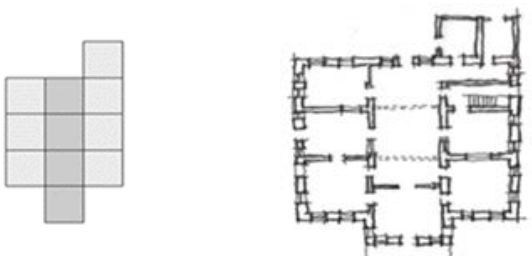

(c)
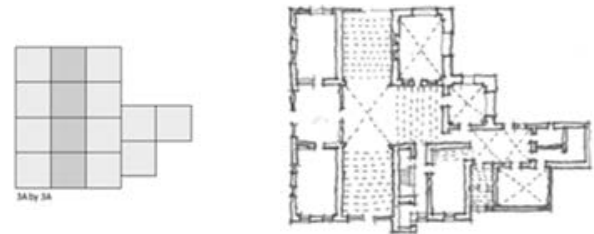

(d)

Figure 5: Extended lane type.

from the integration of new material of timber, red tiles wrought iron export for different parts of the world. In both cases, the central hall house as an extroverted type. It was able to stand free in the street, with its decorated façades and sophisticated decoration that represent the social class of the merchants and reflect a western influence. The red tiles on the roofs, the three triple window at the center of the façades, the use of iron decoration on the balcony are all product of western influence. What makes it unique here is the creative to integrate western solution into local know how.

This paper concludes that the pre-conditions of each city influenced the pattern of evolution of housing in Nablus and Salt. In Nablus, established socio-political and socioreligion factors influenced the architecture, while in Salt, a new social structure was introduced through an immigrant community that settled in the city to benefit from reforms. This community gradually introduced a new style of architecture to reflect their social status. The author also recommends that a comparative analysis should also be carried in the future to cover other areas under the ottoman rule. Area like an Anatolia could be good example. 


\section{REFERENCES}

[1] Alexander, S., Palestine in Transformation, 1856-1882: Studies in Social, Economic and Political Development, 3rd ed., Institute for Palestine Studies: Washington DC, p. 4, 2006.

[2] Bsharah, D., The political economy of population counts in Ottoman Palestine: Nablus, circa 1850. International Journal of Middle East Studies, 26(1), pp. 1-17, 1994.

[3] Salim, F., Palestine and the Decline of the Ottoman Empire: Modernization and the Path to Palestinian Statehood, I.B.Tauris: New York, 1991.

[4] Abu-Hilal, A., The changing architectural style realized in the Palestinian domestic vernacular architecture during the end of $19^{\text {th }}$ /beginning of 20th centuries: Case study from Hebron. PhD thesis, The Graduate School of Natural and Applied Science of Middle East Technical University, 2002.

[5] Rogan, E., Frontiers of the State in the Late Ottoman Empire: Transjordan, 18501921, Cambridge University Press: Cambridge, 2002.

[6] Saliba, R., The Genesis of Modern Architecture in Beirut 1840-1940. Architecture reIntroduced New Projects in Societies in Change, ed. J. Abed, The Aga Khan Award for Islamic Architecture: Geneva, 2004.

[7] Scholch, A., The decline of local power in Palestine after 1856: The case of Aqil Aga. Die Weltdes Islam, 23-24, pp. 458-475, 1984.

[8] Arnuld, J., Modernization of the cities of the Ottoman empire (1800-1920). The City in the Islamic World, eds R. Hold, A. Petruccioli \& A. Raymond, Brill: Leiden, pp. 953-976, 2008.

[9] Turili, I., Istanbul Open City, Exhibiting Anxiety of Urban Modernity, Routledge, 2018.

[10] Howard, L. \& Leonard, T., Comparative frontier history. The Frontier History: North America and Southern Africa Compared, eds H. Lamar \& L. Thomson, Yale University Press: New Haven, CT, pp. 3-14, 1981.

[11] Peter, S., The Urban History of Middle East, 1750-1950, Syracuse University Press, 2008.

[12] Roger, M., Domestic Life in Palestine, Kegan Paul International: London, 1989.

[13] Sluglett, P. \& Farouk Sluglett, M., The application of the 1858 land code in greater Syria. Land Tenure and Social Transformation in the Middle East, ed. T. Khalidi, American University of Beirut: Beirut, pp. 409-421, 1948.

[14] Davidson, R., Reform in the Ottoman Empire, 1856-1876, 2nd ed., New York, 1973.

[15] Ranwa, K. \& Hala, A., The golden era of as-Salt (1870-1950): Urban and architectural development. Studies in the History and Archaeology of Jordan, ed. A. Hadidi, Department of Antiquities of Jordan: Amman, pp. 351-360, 1995.

[16] Ihsan, A., History of Jabal Nablus and Balqaa. (In Arabic.)

[17] Suad, A., Throne Village Architecture - Palestinian Rural Mansions in the Eighteenth and Nineteenth Centuries, RIWAQ-Center for Architectural Conservation: Ramallah, 1992. (In Arabic.)

[18] Fethi, I. \& Rifae, T., Traditional Houses in Baghdad, Horsham, UK, 1993. 